\title{
Physiological potential of soybean seeds produced in southern Brazil
}

\author{
Potencial fisiológico de sementes de soja produzidas no sul do Brasil \\ Potencial fisiológico de las semillas de soja producidas en el sur de Brasil
}

Received: 10/09/2021 | Reviewed: 10/19/2021 | Accept: 10/24/2021| Published: 10/25/2021

\author{
Andressa Villani Perlin \\ ORCID: https://orcid.org/0000-0001-9557-7299 \\ Federal University of Pelotas, Brazil \\ E-mail: andressa.perlin@hotmail.com \\ Cristina Rossetti \\ ORCID: https://orcid.org/0000-0003-2772-5952 \\ Federal University of Pelotas, Brazil \\ E-mail: cristinarosseti@yahoo.com.br \\ Márcio Peter \\ ORCID: https://orcid.org/0000-0002-0275-547X \\ Federal University of Pelotas, Brazil \\ E-mail: marcio.peter@yahoo.com.br \\ Letícia Barão Medeiros \\ ORCID: https://orcid.org/0000-0002-2862-7564 \\ Federal University of Pelotas, Brazil \\ E-mail: lele-medeiros@hotmail.com \\ Jessica Mengue Rolim \\ ORCID: https://orcid.org/0000-0003-2737-7599 \\ Federal University of Pelotas, Brazil \\ E-mail: eng.jessicarolim@gmail.com \\ Cariane Pedroso da Rosa \\ ORCID: https://orcid.org/0000-0002-5597-4123 \\ Federal University of Pelotas, Brazil \\ E-mail: cariane94@hotmail.com \\ Isabela da Rosa Bersch \\ ORCID: https://orcid.org/0000-0002-6698-5362 \\ Federal University of Pelotas, Brazil \\ E-mail: isa1_rosa@yahoo.com.br \\ Tiago Pedó \\ ORCID: https://orcid.org/0000-0003-2737-7599 \\ Federal University of Pelotas, Brazil \\ E-mail: tiago.pedo@gmail.com \\ Tiago Zanatta Aumonde \\ ORCID: https://orcid.org/0000-0003-4790-8270 \\ Federal University of Pelotas, Brazil \\ E-mail: tiago.aumonde@gmail.com \\ Lilian Vanussa Madruga de Tunes \\ ORCID: https://orcid.org/0000-0001-7562-1926 \\ Federal University of Pelotas, Brazil \\ E-mail: lilianmtunes@yahoo.com.br
}

\begin{abstract}
Soy is the most economically important agricultural crop in the world. Achieving higher productivity has been a challenge in today's agriculture. Making the seed, surely, the most important input for agricultural development, because, as a living organism, it is depositary, directly or indirectly, of a large part of the technological advances developed by researchers over decades. Therefore, the successful implantation of a crop is in the use of seeds of high physiological quality, with a high percentage of germination and vigor. Thirty cultivars and 29 cities were used, totaling 131 samples from the three southern Brazilian states. Being evaluated the physiological quality, as well as its components, germination, accelerated aging at $41^{\circ} \mathrm{C}$ for 48 hours, tetrazolium test, and mass of a thousand seeds. For the macronutrient tests, nitrogen $(\mathrm{N})$, phosphorus $(\mathrm{P})$, potassium $(\mathrm{K})$, Calcium $(\mathrm{Ca})$ and Molybdenum (Mo) were analyzed. At the end of this work, it can be concluded that the three states in the south of Brazil did not present differences regarding the physiological quality of the tested cultivars. However, the physiological potential comprises the set of skills that allows estimating the capacity of a batch of seeds to properly manifest their vital functions after sowing.
\end{abstract}

Keywords: Glycine max; Southern Region; Nutrients; Seed quality. 


\begin{abstract}
Resumo
A soja é a cultura agrícola de maior importância econômica do mundo. Alcançar maior produtividade tem sido um desafio na agricultura de hoje. Fazendo da semente, com certeza, o insumo mais importante para o desenvolvimento agrícola, pois, como organismo vivo, é depositária, direta ou indiretamente, de grande parte dos avanços tecnológicos desenvolvidos por pesquisadores ao longo de décadas. Portanto, o sucesso da implantação de uma cultura está na utilização de sementes de alta qualidade fisiológica, com alto percentual de germinação e vigor. Foram utilizadas 30 cultivares e 29 cidades, totalizando 131 amostras dos três estados do sul do Brasil. Sendo avaliada a qualidade fisiológica, bem como seus componentes, germinação, envelhecimento acelerado a $41^{\circ} \mathrm{C}$ por 48 horas, teste de tetrazólio e massa de mil sementes. Para os testes de macronutrientes, foram analisados nitrogênio (N), fósforo (P), potássio $(\mathrm{K})$, cálcio $(\mathrm{Ca})$ e molibdênio $(\mathrm{Mo})$. Ao final deste trabalho, pode-se concluir que os três estados do sul do Brasil não apresentaram diferenças quanto à qualidade fisiológica das cultivares testadas. Porém, o potencial fisiológico compreende o conjunto de habilidades que permite estimar a capacidade de um lote de sementes em manifestar adequadamente suas funções vitais após a semeadura.
\end{abstract}

Palavras-chave: Glycine max; Região Sul; Nutrientes; Qualidade de sementes.

\title{
Resumen
}

La soja es el cultivo agrícola más importante económicamente del mundo. Alcanzar una mayor productividad ha sido un desafío en la agricultura actual. Haciendo de la semilla, seguramente, el insumo más importante para el desarrollo agrícola, pues, como organismo vivo, es depositario, directa o indirectamente, de gran parte de los avances tecnológicos desarrollados por los investigadores a lo largo de décadas. Por tanto, la implantación exitosa de un cultivo está en el uso de semillas de alta calidad fisiológica, con un alto porcentaje de germinación y vigor. Se utilizaron treinta cultivares y 29 ciudades, totalizando 131 muestras de los tres estados del sur de Brasil. Evaluándose la calidad fisiológica, así como sus componentes, germinación, envejecimiento acelerado a $41^{\circ} \mathrm{C}$ durante 48 horas, prueba de tetrazolio, y masa de mil semillas. Para las pruebas de macronutrientes se analizaron nitrógeno (N), fósforo $(\mathrm{P})$, potasio $(\mathrm{K})$, calcio $(\mathrm{Ca})$ y molibdeno $(\mathrm{Mo})$. Al final de este trabajo, se puede concluir que los tres estados del sur de Brasil no presentaron diferencias en cuanto a la calidad fisiológica de los cultivares probados. Sin embargo, el potencial fisiológico comprende el conjunto de habilidades que permite estimar la capacidad de un lote de semillas para manifestar adecuadamente sus funciones vitales después de la siembra.

Palabras clave: Glycine max; Región Sur; Nutrientes; Calidad de semilla.

\section{Introduction}

Soy today is one of the main products in the agribusiness chain, being used as currency in the hands of farmers, cerealists and brokers, and can multiply gains for those who can understand its vast market, which contributes to the increase in Brazilian GDP (gross domestic product) (IBGE, 2016). According to the Ministry of Agriculture (MAPA, 2018) the increase in productivity is associated with technological advances, management and efficiency of producers. Its grain being the essential component in the manufacture of animal feed and with increasing use in human food. According to data from Embrapa Soja (2019), Brazil is expecting to overtake the United States in soybean cultivated area and, if weather conditions permit, it will become the main world producer of the grain. In the 2018/2019 harvest, the crop occupied a planted area of 35,455 million hectares, which totaled a production of 114,843 million tons. The average productivity of Brazilian soybeans was 3,206 kg per hectare (USDA, 2019).

The Santos e Silveira (2017) point out, the soybean culture in Brazil, which was first established in the southern states of the country, was born with high yields and, since the 1970s, has been responsible for numerous metamorphoses and productive specializations in the area Brazilian agrarian. Currently, Rio Grande do Sul is the third largest soy producer in the country. In the 2017/2018 harvest the area occupied by the crop was 5,692.1 thousand hectares, and the total production is estimated at 17,543.1 thousand tons (CONAB, 2018). The state also stands out in the production and commercialization of seeds, according to the Catalog of Producers of Seeds and Seedlings of Rio Grande do Sul (CSM / RS, 2016). While, in Santa Catarina, soy production is equivalent to $2 \%$ of national production, being the 11 th federation unit (UF), which produces the most soy in the Brazilian territory (CONAB, 2016). Whereas Paraná is the second largest soybean producer in Brazil. Even in the last harvests, Paraná has shown a significant increase in production, reaching approximately 23.3 million tons of grains in 
the 2019/2020 harvest (DERAL, 2020). Thus, for Brazilian productivity to become increasingly higher, it is essential that the seeds used express their full potential. It is known that the production of soybeans with a high standard is a major challenge to the productive sector (EMBRAPA, 2016). Therefore, in order for this objective to be achieved, it is essential to invest in a good quality control system.

According to PESKE et al., (2010), when it comes to seed quality, we can mention the physiological quality to which it is represented by the germination and vigor of the seeds, where all of them need to germinate and emerge to become a plant. it is also understood that when it comes to the nutrient reserve in the seed, it is understood that this is expressed by the levels found in the constituent parts of the seed. This value varies between species, cultivars and depends on the environmental conditions in which the seed is produced (Carvalho \& Nakagawa, 2016).

The mobilization of reserves in seed embryos of different species has also been studied by different authors. As well as it is important to consider the nutritional presence of the seeds because, according to Carvalho e Nakagawa, (2016), the nutrients stored in the seed will supply the necessary elements for the establishment of the seedling in its initial stages. Thus, seeds with high physiological, chemical and nutritional potential provide increased productivity of soybean crops (Fessel et al., 2018).

Therefore, this study aimed to describe the physiological potential and chemical composition of soybean seeds in the Southern Region of Brazil.

\section{Methodology}

The study was conducted from data obtained by the Seed Analysis - Fertiláqua laboratory which is located in Cruz Alta - RS. The states selected are those in the South of Brazil: Paraná, Santa Catarina and Rio Grande do Sul (Figure 1). A total of 30 (thirty) cultivars were selected for the research, and these are distributed according to tables 1 and 2.

Table 1. Distribution of cultivars according to cities in the three southern states of Brazil

\begin{tabular}{c|cc}
\hline States & Samples & Cities \\
\hline Rio Grande do Sul & 63 & 16 \\
Santa Catarina & 10 & 2 \\
Paraná & 58 & 11 \\
Total & 131 & 29 \\
\hline
\end{tabular}

Source: Authors. 
Table 2. Cities selected for research development according to their respective characteristics of climate and soil structure.

\begin{tabular}{|c|c|c|c|c|c|}
\hline County & UF & Latitude & Longitude & Altitude & Soil type \\
\hline CASTRO & PR & $24^{\circ} 47^{\prime} 28^{\prime \prime} \mathrm{S}$ & $50^{\circ} 00^{\prime} 43^{\prime \prime} \mathrm{W}$ & $996 \mathrm{~m}$ & Red Argisol \\
\hline ENGENHEIRO BELTRÃO & PR & $23^{\circ} 48^{\prime} 16^{\prime \prime} \mathrm{S}$ & $52^{\circ} 15^{\prime} 19^{\prime \prime} \mathrm{W}$ & $444 \mathrm{~m}$ & Red Latosol \\
\hline GUARAPUAVA & PR & $25^{\circ} 23^{\prime} 37^{\prime \prime} \mathrm{S}$ & $51^{\circ} 27^{\prime} 22^{\prime \prime} \mathrm{W}$ & $1111 \mathrm{~m}$ & Oxisol bruno \\
\hline IMBITUVA & PR & $25^{\circ} 13^{\prime} 49^{\prime \prime} \mathrm{S}$ & $50^{\circ} 36^{\prime} 30^{\prime \prime} \mathrm{W}$ & $878 \mathrm{~m}$ & Oxisol bruno \\
\hline LARANJEIRAS DO SUL & PR & $25^{\circ} 24^{\prime} 28^{\prime \prime} \mathrm{S}$ & $52^{\circ} 24^{\prime} 58^{\prime \prime} \mathrm{W}$ & $840 \mathrm{~m}$ & Nitossolo \\
\hline LONDRINA & PR & $23^{\circ} 17^{\prime} 34^{\prime \prime} \mathrm{S}$ & $51^{\circ} 10^{\prime} 24^{\prime \prime} \mathrm{W}$ & $550 \mathrm{~m}$ & Red Latosol \\
\hline MAMBORÊ & PR & $24^{\circ} 16^{\prime} 30^{\prime \prime} \mathrm{S}$ & $52^{\circ} 30^{\prime} 41^{\prime \prime} \mathrm{W}$ & $763 \mathrm{~m}$ & Purple Oxisol \\
\hline MARIALVA & PR & $23^{\circ} 29^{\prime} 8^{\prime \prime} \mathrm{S}$ & $51^{\circ} 47^{\prime} 34^{\prime \prime} \mathrm{W}$ & $644 \mathrm{~m}$ & Red Latosol \\
\hline PONTA GROSSA & PR & $25^{\circ} 05^{\prime} 42^{\prime \prime} \mathrm{S}$ & $50^{\circ} 09^{\prime} 43^{\prime \prime} \mathrm{W}$ & $969 m$ & Oxisol bruno \\
\hline TEIXEIRA SOARES & PR & $25^{\circ} 22^{\prime} 4^{\prime \prime} \mathrm{S}$ & $50^{\circ} 27^{\prime} 20^{\prime \prime} \mathrm{W}$ & $911 \mathrm{~m}$ & Cambisol \\
\hline TIBAGI & PR & $24^{\circ} 30^{\prime} 6^{\prime \prime} \mathrm{S}$ & $50^{\circ} 26^{\prime} 30^{\prime \prime} \mathrm{W}$ & $793 m$ & Red Argisol \\
\hline VENTANIA & PR & $24^{\circ} 14^{\prime} 40^{\prime \prime} \mathrm{S}$ & $50^{\circ} 14^{\prime} 36^{\prime \prime} \mathrm{W}$ & $1025 \mathrm{~m}$ & Red Argisol \\
\hline CAMPESTRE DA SERRA & $\mathrm{RS}$ & $28^{\circ} 47^{\prime} 9^{\prime \prime} \mathrm{S}$ & $51^{\circ} 5^{\prime} 55^{\prime \prime} \mathrm{W}$ & $807 \mathrm{~m}$ & NeosolLitolic \\
\hline CAPÃO BONITO DO SUL & $\mathrm{RS}$ & $28^{\circ} 6^{\prime} 6^{\prime \prime} \mathrm{S}$ & $51^{\circ} 23^{\prime} 24^{\prime \prime} \mathrm{W}$ & $818 m$ & Red Latosol \\
\hline CRUZ ALTA & $\mathrm{RS}$ & $28^{\circ} 38^{\prime} 22^{\prime \prime} \mathrm{S}$ & $53^{\circ} 36^{\prime} 22^{\prime \prime} \mathrm{W}$ & $476 \mathrm{~m}$ & Red Latosol \\
\hline ESPUMOSO & $\mathrm{RS}$ & $28^{\circ} 43^{\prime} 29^{\prime \prime} \mathrm{S}$ & $52^{\circ} 50^{\prime} 59^{\prime \prime} \mathrm{W}$ & $357 \mathrm{~m}$ & Red Latosol \\
\hline IBIRAIARAS & $\mathrm{RS}$ & $28^{\circ} 22^{\prime} 12^{\prime \prime} \mathrm{S}$ & $51^{\circ} 38^{\prime} 11^{\prime \prime} \mathrm{W}$ & $776 \mathrm{~m}$ & Red Latosol \\
\hline IBIRUBA & $\mathrm{RS}$ & $28^{\circ} 37^{\prime} 48^{\prime \prime} \mathrm{S}$ & $53^{\circ} 5^{\prime} 25^{\prime \prime} \mathrm{W}$ & $400 \mathrm{~m}$ & Red Latosol \\
\hline MACHADINHO & $\mathrm{RS}$ & $27^{\circ} 34^{\prime} 4^{\prime \prime} \mathrm{S}$ & $51^{\circ} 40^{\prime} 11^{\prime \prime} \mathrm{W}$ & $747 \mathrm{~m}$ & Yellow Latosol \\
\hline PEDRO OSORIO & $\mathrm{RS}$ & $31^{\circ} 52^{\prime} 47^{\prime \prime} \mathrm{S}$ & $52^{\circ} 48^{\prime} 37^{\prime \prime} \mathrm{W}$ & $44 \mathrm{~m}$ & Litossolo \\
\hline PORTO ALEGRE & $\mathrm{RS}$ & $30^{\circ} 1^{\prime} 40^{\prime \prime} \mathrm{S}$ & $51^{\circ} 13^{\prime} 43^{\prime \prime} \mathrm{W}$ & $22 \mathrm{~m}$ & Red Argisol \\
\hline RESTINGA SECA & $\mathrm{RS}$ & $28^{\circ} 13^{\prime} 13^{\prime \prime} \mathrm{S}$ & $54^{\circ} 20^{\prime} 20^{\prime \prime} \mathrm{W}$ & $272 \mathrm{~m}$ & Neosol Litolic \\
\hline SÃO GABRIEL & $\mathrm{RS}$ & $30^{\circ} 20^{\prime} 38^{\prime \prime} \mathrm{S}$ & $54^{\circ} 20^{\prime} 31^{\prime \prime} \mathrm{W}$ & $118 \mathrm{~m}$ & Red Latosol \\
\hline SALTO DO JACUI & $\mathrm{RS}$ & $29^{\circ} 5^{\prime} 16^{\prime \prime} \mathrm{S}$ & $53^{\circ} 12^{\prime} 27^{\prime \prime} \mathrm{W}$ & $306 \mathrm{~m}$ & Red Latosol \\
\hline SOLEDADE & $\mathrm{RS}$ & $7^{\circ} 3^{\prime} 27^{\prime \prime} \mathrm{S}$ & $36^{\circ} 21^{\prime} 47^{\prime \prime} \mathrm{W}$ & $523 \mathrm{~m}$ & Red Argisol \\
\hline TUPANCIRETÃ & $\mathrm{RS}$ & $29^{\circ} 4^{\prime} 57^{\prime \prime} \mathrm{S}$ & $53^{\circ} 50^{\prime} 13^{\prime \prime} \mathrm{W}$ & $466 \mathrm{~m}$ & Argisol \\
\hline VACARIA & $\mathrm{RS}$ & $28^{\circ} 30^{\prime} 39^{\prime \prime} \mathrm{S}$ & $50^{\circ} 55^{\prime} 47^{\prime \prime} \mathrm{W}$ & $960 \mathrm{~m}$ & Oxisol bruno \\
\hline CAMPOS NOVOS & $\mathrm{SC}$ & $27^{\circ} 24^{\prime} 7^{\prime \prime} \mathrm{S}$ & $51^{\circ} 13^{\prime} 33^{\prime \prime} \mathrm{W}$ & $925 \mathrm{~m}$ & Cambisol \\
\hline SAUDADES & $\mathrm{SC}$ & $26^{\circ} 55^{\prime} 27^{\prime \prime} \mathrm{S}$ & $53^{\circ} 00^{\prime} 11^{\prime \prime} \mathrm{W}$ & $280 \mathrm{~m}$ & Red Latosol \\
\hline
\end{tabular}

Source: Authors. 
Figure 1. Map with the distribution of cities according to their climate and soil characteristics.

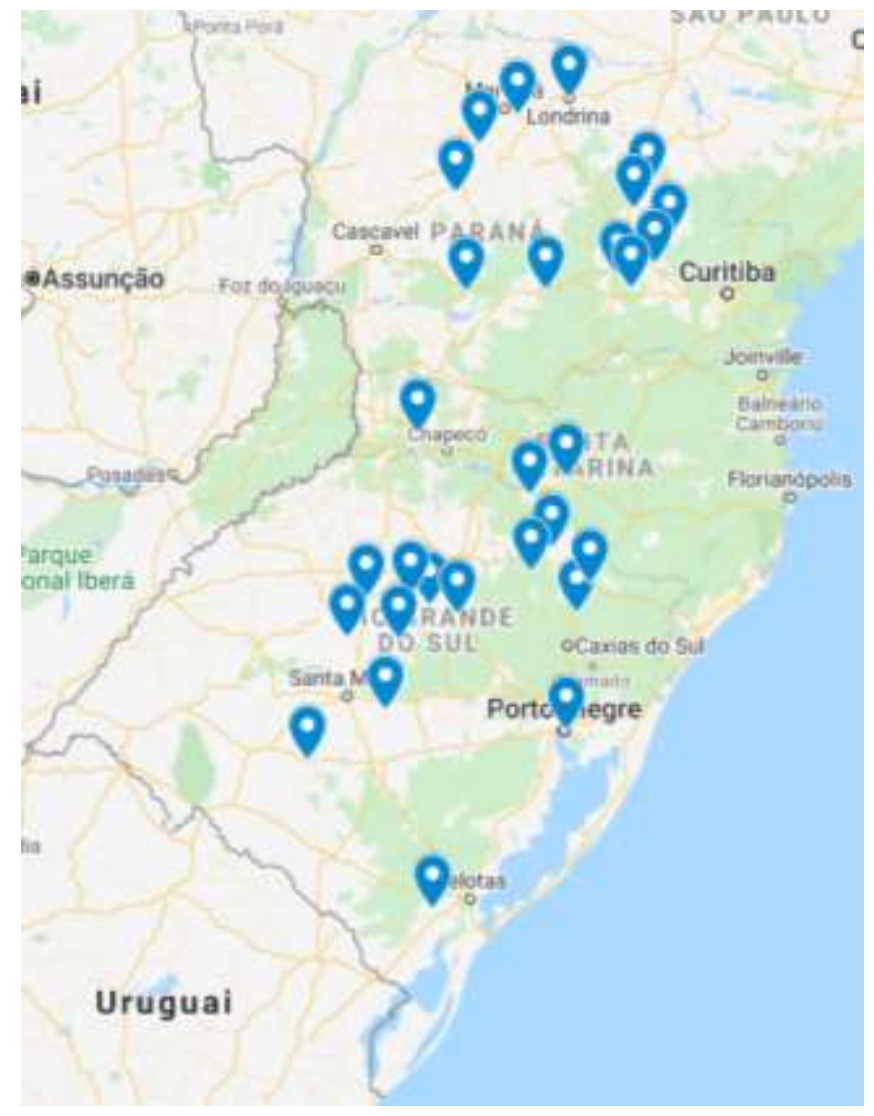

Source: google.com/Maps. Pelotas, July 27 (2020).

For carrying out the laboratory analyzes, samples of $1.0 \mathrm{~kg}$ of seeds were collected from each cultivar. For the assessment of physiological quality and chemical composition we will use the following tests:

Germination test: conducted with eight sub-samples of 50 seeds whose sowing was carried out on germitest ${ }^{\circledR}$ paper substrate in the form of rolls formed by three leaves previously moistened with distilled water in an amount equivalent to 2.5 times its dry mass. The rolls must be arranged in a germinator, placed upright in polyethylene envelopes and kept in a germination room at a constant temperature of $25^{\circ} \mathrm{C}$ and a luminous period of $12 \mathrm{~h}$. Evaluations are carried out eight days after sowing and the results are expressed as a percentage of normal seedlings, as indicated by the Rules for Seed Analysis (BRASIL, 2009).

Accelerated aging: the method described by Krzyzanowski et al. (1999), with four replications of 50 seeds, arranged on a galvanized wire mesh tray, fixed inside plastic boxes (gerbox) to which contains $40 \mathrm{ml}$ of distilled water. The samples are incubated in germination chambers of the BOD type (Biochemical Oxygen Demand), at a constant temperature of $41^{\circ} \mathrm{C}$ for 48 hours. After this period, the seeds were placed to germinate following the same procedures used in the germination test and the count of normal seedlings is performed at 4 days after sowing. The results are expressed as a percentage of live seedlings.

Mass of a thousand seeds: using three replications with eight subsamples of one hundred seeds, seedling counting was performed at 4 days after sowing. Subsequently, the average mass is multiplied by ten, thus obtaining the mass of a thousand seeds. The data average is expressed in grams (Brasil, 2009).

Tetrazolium test: performed with two repetitions of 50 seeds pre-packed in germitest ${ }^{\circledR}$ paper, moistened and folded in order to better condition the reproductive structure, being wrapped in a polyethylene envelope and kept at room temperature $\left( \pm 25^{\circ} \mathrm{C}\right)$ for the period 16 hours. The seeds must be kept submerged in a tetrazolium solution $(0.50 \mathrm{~g}-1000 \mathrm{~mL}-1)$, placed in 
$50 \mathrm{ml}$ polyethylene cups, kept at 38 to $40^{\circ} \mathrm{C}$ in a germinator, for three hours and subsequently evaluated individually, with cuts through the embryonic axis to observe the color differentiation of the tissues, as follows: a) carmine red - vivid and vigorous tissue; b) strong red - deteriorating tissue and milky white - dead tissue. To compose the percentage of vigorous seeds, the results of classes 1, 2 and 3 are added, while for the percentage of viable seeds are the results of classes 1, 2, 3, 4 and 5 .

To determine the content of nutrients in the seeds: $0.2 \mathrm{~g}$ of tissue was measured and submitted to acid digestion and with high temperature to transform the nutrients from organic forms to minerals. Subsequently, the total $\mathrm{N}$ content by the Kjeldahl distillation method and the P content determined by visible spectrophotometry (Tedesco et al., 1995). The levels of K, $\mathrm{Ca}$ and Mo were determined by atomic absorption spectrophotometry (Tedesco et al., 1995).

Statistical analysis: The statistical design used was completely randomized with 30 cultivars and 29 cities, totaling 131 samples. Descriptive statistical analysis and the use of Microsoft Excel 2013 software were used to obtain the averages and prepare treatment charts.

\section{Results and Discussion}

According to the statistical analysis carried out, we can see in Graph 1, that both tests in which they evaluated germination, vigor due to accelerated aging and the tetrazolion test did not obtain significant differences in their results, regardless of the state of the south of Brazil in the study that was carried out. sowing and harvesting.

Thus, verifying that both cultivars tested regardless of the edaphoclimatic characteristics of the regions that were produced, presented high physiological quality, meeting the minimum standards required by law for commercialization. According to Mielezrkiet al., (2008), the use of high quality seeds physiological quality assumes a fundamental role in the conduction of a crop to achieve high yields, since high quality seeds present greater speed in the metabolic processes, providing faster and uniform emission of the primary root in the germination process and higher growth rate, producing seedlings with greater initial stature and, consequently, greater growth and grain yield. 
Graph 1: Summary of the physiological potential of soybean seeds according to each state under study.

\section{Seed Quality}
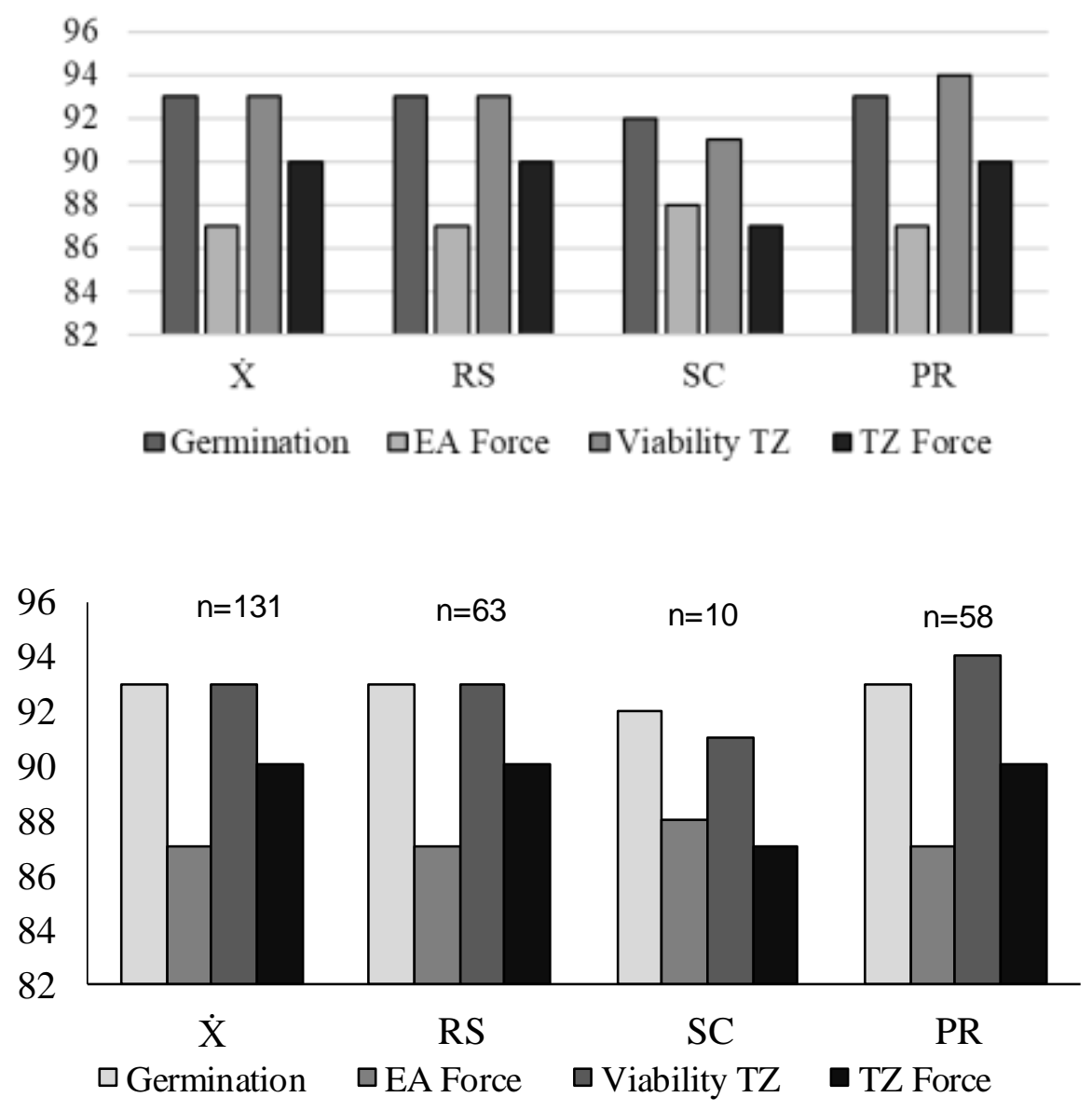

Source: Authors.

When it comes to the germination of soybean seeds, it can be seen in Graph 2, that all 30 cultivars tested, had their germination potential greater than $90 \%$, obtaining approximately $25 \%$ of these cultivars with germination greater than $95 \%$.

Graph 2: Frequency of germination regardless of the state under study.

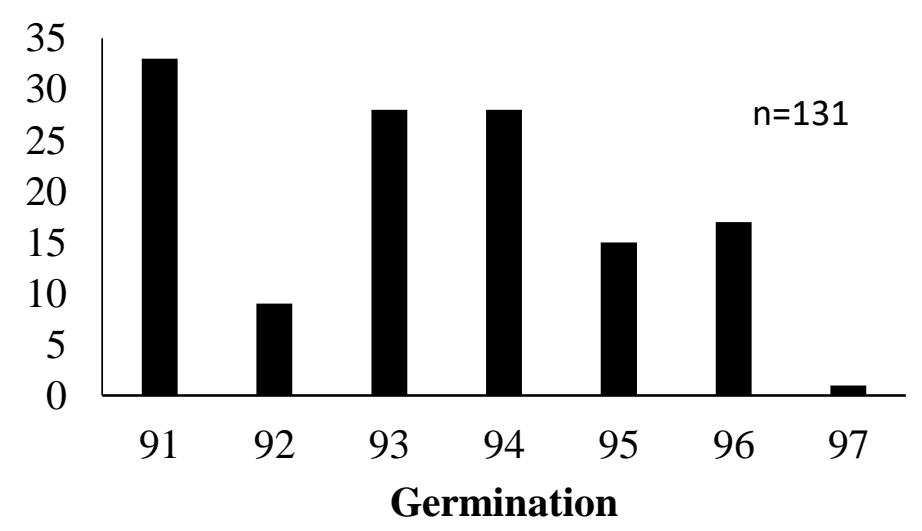

Source: Authors. 
Regarding seed vigor (EA), 27 of the 30 cultivars tested obtained vigor above $80 \%$, as can be seen in Graph 3 . When comparing the three states, Santa Catarina is the one with the highest percentage of vigor, between 88 and $90 \%$, while Rio Grande do Sul and Paraná show an average of $85 \%$ vigor (Graph 1).

Considering that, the accelerated aging test assesses the degree of tolerance of the seeds at a temperature that varies between $41^{\circ} \mathrm{C}$ to $45^{\circ} \mathrm{C}$ and relative humidity that contribute to accelerating the deterioration process.

In general, for both states the highest frequency in terms of vigor by the Accelerated Aging test ranges from 88 to $92 \%$ (Graph 3), thus confirming that this allows the establishment of more vigorous seeds, with germination greater than $91 \%$ (Graph 2), with more than $60 \%$ of the cultivars analyzed located at the frequency of $92 \%$ germination after this artificial aging.

Graph 3: Frequency of the vigor test assessed by Accelerated Aging regardless of the state under study.

\section{Frequency}

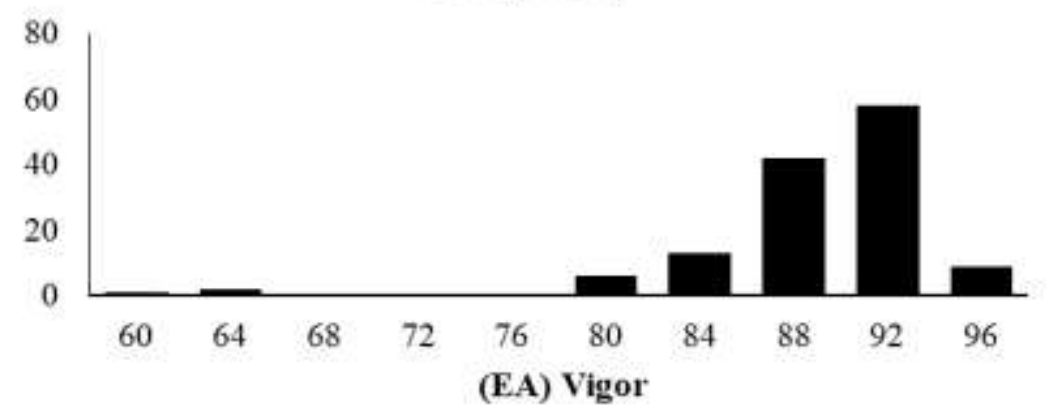

Source: Authors.

For the distribution of vigor by the tetrazolium test (TZ) as seen in Figure 2, the cultivars tested have, in general, high vigor, highlighting that more than $40 \%$ of the tested cultivars showed vigor above $93 \%$. We can also point out that $15 \%$ of the cultivars obtained results above $96 \%$ of vigor by TZ.

In general, the cultivars produced in the state of Paraná, exhibited the highest vigor classification when compared to the other states under study. Hennigen et al. (2015), found that plants from seeds of the highest vigor produce $25 \%$ more pods per plant, resulting in experimental plots with 35\% more grain yield than those from seeds of low vigor. When comparing the two vigor tests, accelerated aging (graph 3) and tetrazolium test (Figure 2), the results presented were similar, with the seeds being classified as high quality, with no statistical differences in vigor between them. 
Figure 2: Distribution and frequency of the classes of the vigor test performed from the tetrazolium in soybean seeds (Glycine $\max$ ) in the three southern states of Brazil.
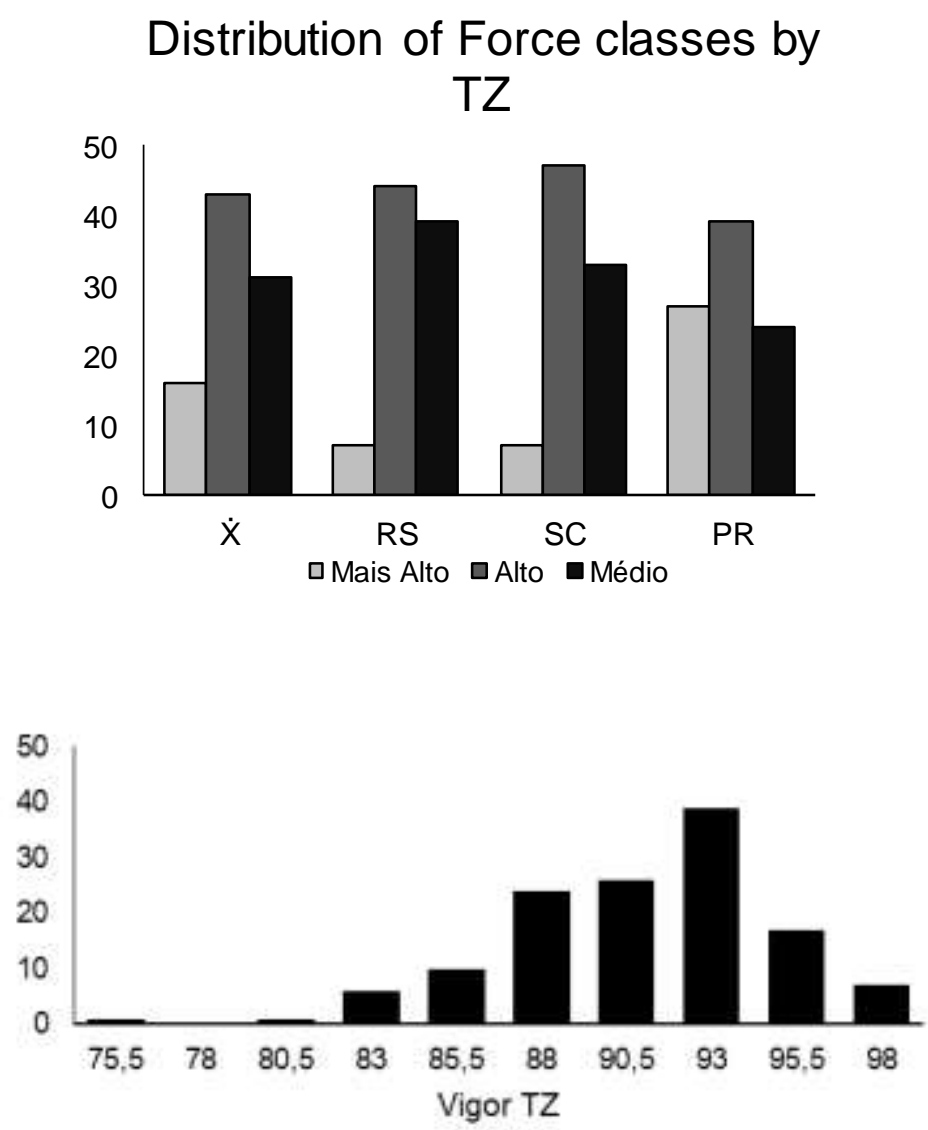

Source: Authors.

Analyzing the data from the tetrazolium test for viability (class 1 to 5), a quality gradient ranging between $89.5 \%$ and 99\% was observed (Graph 4). As Steiner e Kruse (2003) describe "seed viability” as a strong impact on the development of the tetrazolium test. Thus defining the term viability as a potential for germination and therefore a seed at rest as a type of seedling potential.

Graph 4: Frequency of soybean seed Viability according to the tetrazolium test regardless of the state under study.

\section{Frequency}

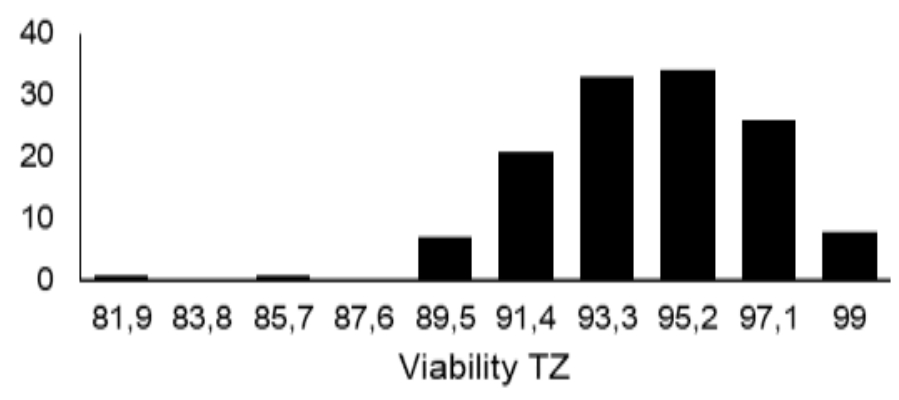


In the evaluation, the Weight of a Thousand Seeds (PMS) of large seeds was higher than that of small ones, where the highest frequency is $184.78 \mathrm{~g}$, where more than $60 \%$ of the results obtained in the tests are in the frequency range of $146.515 \mathrm{ga}$ $197.535 \mathrm{~g}$ (Figure 3)

It is understood that the weight of a thousand seeds of a sample (PMS) is used to calculate the sowing density, the number of seeds per package and the weight of the working sample for purity analysis. The state of Paraná had seeds with the highest PMS (Figure 3), averaging 175 grams followed by Santa Catarina with seeds weighing approximately 170 grams and Rio Grande do Sul reaching 10 grams less than Paraná. When observing the relationship between the vigor tests for both AE (Graph 3) and TZ (Figure 2), the seeds that are smaller in size do not have significant differences when compared to the seeds of larger size. The vigor results, evaluated by the accelerated aging test (Graph 3), show results similar to those observed in the tetrazolium test (Figure 2), in which more than $50 \%$ of the cultivars tested in both tests are within the highest frequency with $92-93 \%$ vigor.

Figure 3: Seed PMS ratio according to each State and the frequency of the Thousand Seeds Weight in soybean seeds (Glycine max) regardless of the State.

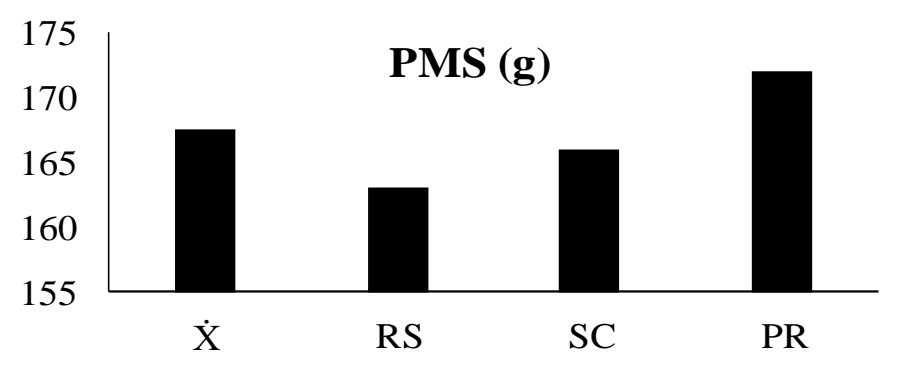

\section{Frequency}

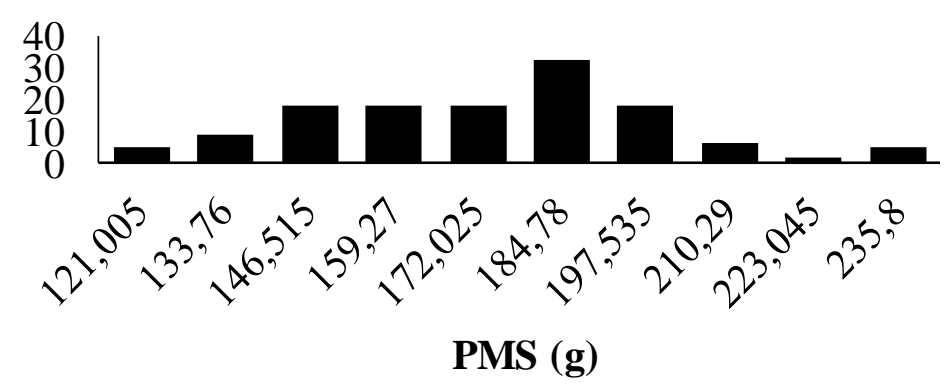

Source: Authors.

In general, the results of the analysis showed that there was a correlation between the levels of macronutrients contained in soybean seeds and the physiological quality of the different cultivars, with no significant difference in the amount of nutrients between the states under study (Graph 5).

The physiological quality of seeds can be influenced, both positively and negatively, by numerous factors. Within this context, nutrients can play a prominent role. Soybean seeds of different cultivars and lots can vary in chemical composition due to cultivation in different environmental conditions, with potential effects on physiological quality (Delarmino - Ferraresi et al., 2014). 
Graph 5: Content of the nutrients nitrogen $(\mathrm{N})$, phosphorus $(\mathrm{P})$ and potassium $(\mathrm{K})$ contained in soybean seeds represented in $\mathrm{g}$ $/ \mathrm{kg}$ according to each of the three States.

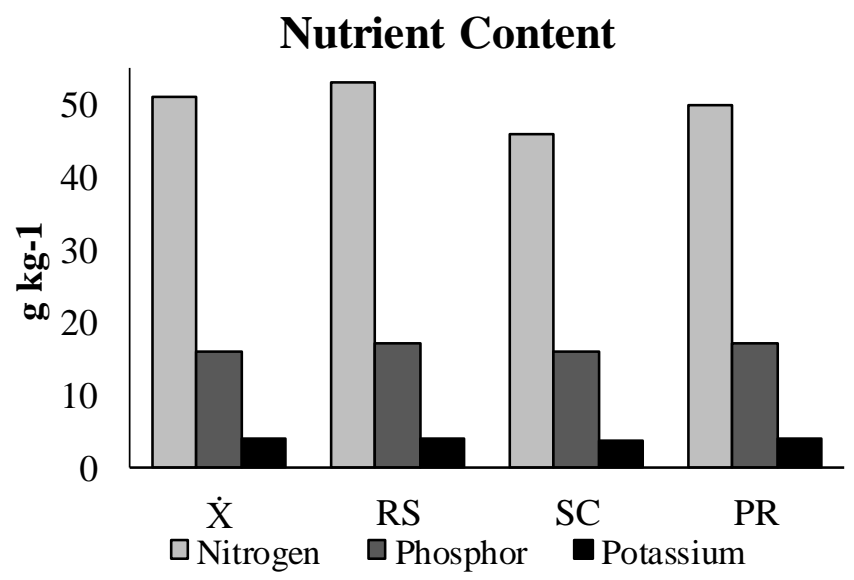

Source: Authors.

The nitrogen content present in the seeds of the 30 cultivars varies from $44.5 \mathrm{~g} / \mathrm{kga}$ to $65.5 \mathrm{~g} / \mathrm{kg}$, obtaining a higher concentration of this nutrient in $55.03 \mathrm{~g} / \mathrm{kg}$ (Graph 6). The higher nitrogen concentration may be related to greater germination and greater vigor, determined by accelerated aging, due to the fact that, in soy, the availability of nitrogen, together with the genetic potential of the variety, influences the protein content of the seeds (Delarmino - Ferraresi et al., 2014).

These proteins will be used in the early stages of germination, either in the form of enzymes or in the form of preexisting mRNA. Since the reserve proteins are hydrolyzed during seed germination and will provide the nutrition that the embryo needs during germination (Zimmer, 2012).

Graph 6: Frequency of nitrogen $(\mathrm{N})$ present in the seeds of the cultivars analyzed, regardless of the State.

\section{Frequency}

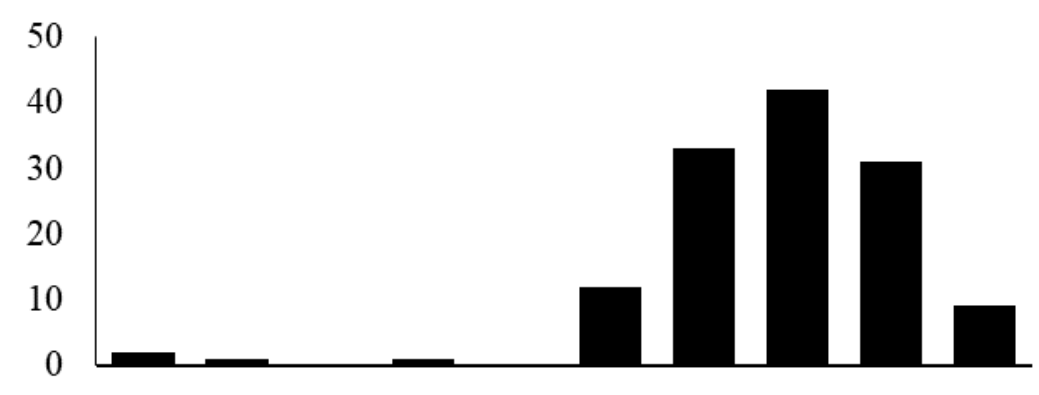

$18,2323,4928,7434,0039,2644,5249,7855,0360,2965,55$

Nitrogen

Source: Authors. 
When it comes to phosphorus, the highest frequency found for the cultivars tested is within $4.30 \mathrm{~g} / \mathrm{kg}$, ranging from $2.24 \mathrm{~g} / \mathrm{kg}$ to $4.89 \mathrm{~g} / \mathrm{kg}$ (Graph 7). Thus, the phosphorus that is present in the seeds, mainly as a structural component of the phospholipid membranes, phosphoproteins, phospholipids, as a component of nucleic acids and many coenzymes. It can also be found in inorganic form, stored in vacuoles as orthophosphate. Its main functions are related to the production of chemical energy for physiological reactions (Zimmer, 2012).

Also concluded by the same author, when in conditions of $\mathrm{P}$ deficiency in the culture, the reserves of inorganic phosphorus present in the vacuoles are used, while the organic P remains. The greater availability of this element during seed formation may result in greater accumulation of inorganic P in vacuoles and, consequently, greater availability of energy for reactions during germination.

Graph 7: Frequency of phosphorus (P) present in the seeds of the cultivars analyzed, regardless of the State.

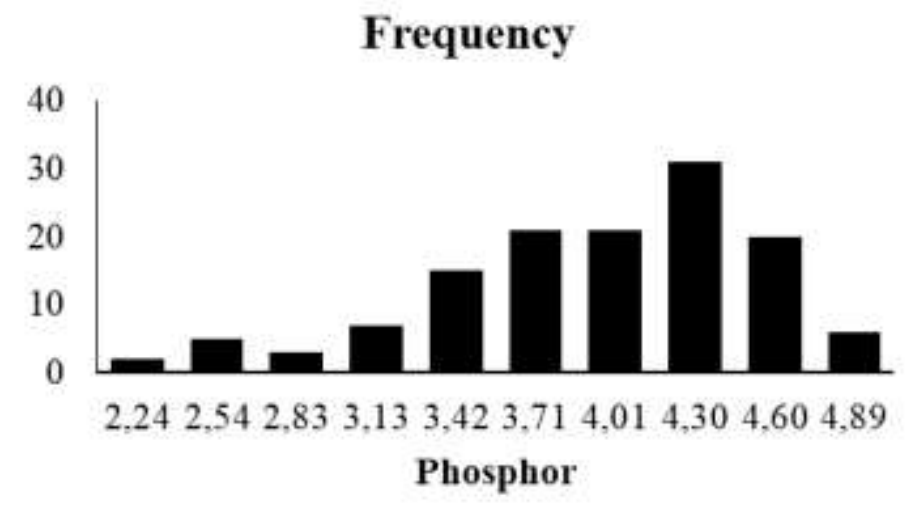

Source: Authors.

Assessing the frequency of potassium, it is observed for the cultivars tested that the highest content is $17 \mathrm{~g} / \mathrm{kg}$, varying within the frequency range $12.3 \mathrm{~g} / \mathrm{kg}$ to $23 \mathrm{~g} / \mathrm{kg}$ of potassium (graph 08). Only one of the crops tested had a high potassium content, reaching $26 \mathrm{~g} / \mathrm{kg}$ of potassium.

It is known that the potassium content in seeds is important in the initial stage of plant growth, when the root system is poorly developed for the adequate supply of plant with this nutrient, since it is essential due to the various functions it performs within the plant, (Malavolta, 2016; Epstein \& Bloom, 2016). Among these various functions that this nutrient plays in plant metabolism, the most important is the control of water absorption, enzymatic activation, growth of meristematic tissues, synthesis of proteins and carbohydrates, translocation of assimilates and opening and closing of stomata (Veiga et al., 2010). 
Graph 8: Frequency of potassium $(\mathrm{K})$ present in the seeds of the cultivars analyzed, regardless of the State.

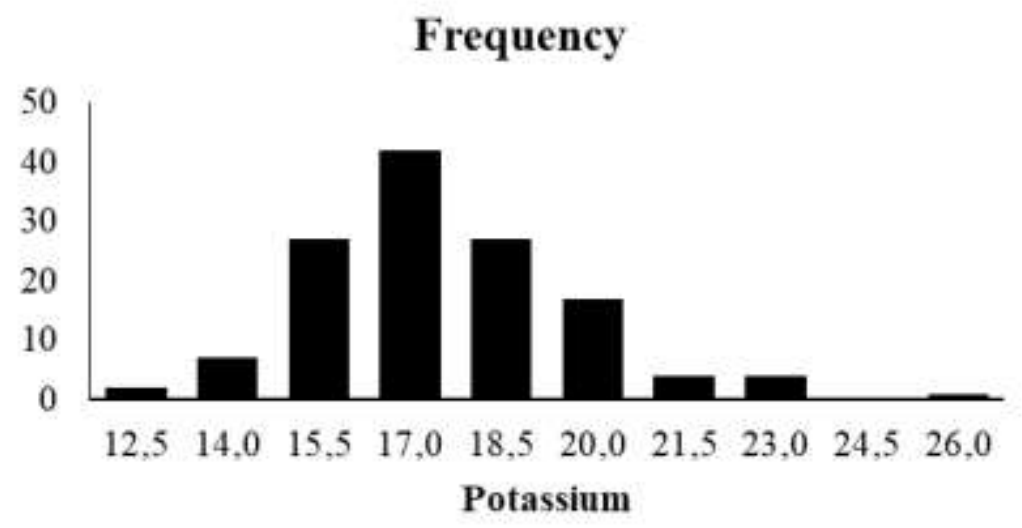

Source: Authors.

Regarding the nutrients Calcium (Ca) and Molybdenum (Mo), it is observed that the states of Rio Grande do Sul and Santa Catarina do not present significant differences, while Parana presents differences for both analyzed nutrients. Both calcium and molybdenum deficiency can negatively influence the nitrogen nutrition of soybean plants, mainly because the crop is a legume and the deficiency of these nutrients can affect the efficiency of biological nitrogen fixation (Flores et al., 2015).

Graph 9: Calcium (Ca) and Molybdenum (Mo) contents present in the tested cultivars separated by State.

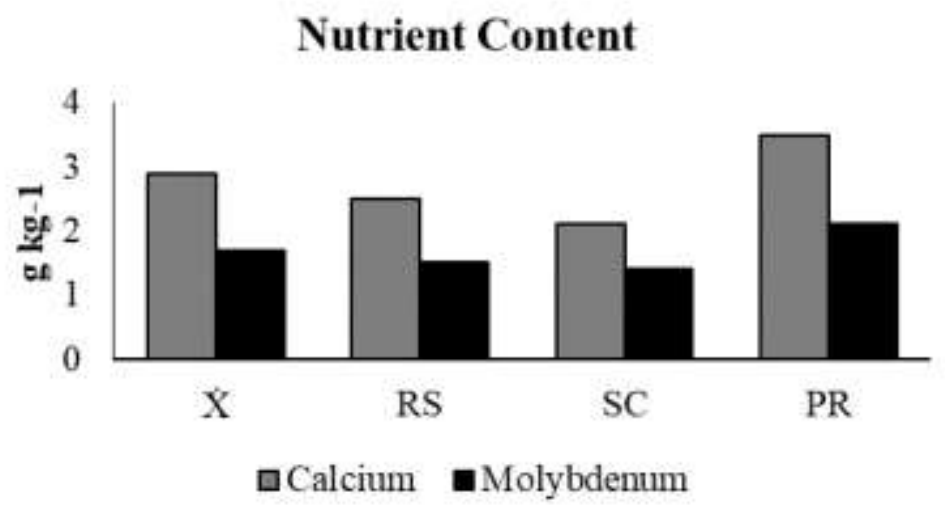

Source: Authors.

The application of Ca favored the development, accumulation of biomass in the aerial part of the soy plants (Silva et al., 2011). According to Farinelli et al. (2016) the foliar fertilization with Ca promotes an increase in grain yield. Calcium is important in preserving the absorption capacity of the roots by maintaining the integrity of the plasma membrane, as well as preventing the loss of solutes to the external solution, influencing so, in general, the acquisition of nutrients by plants (Malavolta, 2016).

In general, the results found for $\mathrm{Mo}$ and $\mathrm{Ca}$ present in the seed, provide a significant increase in all agronomic characteristics analyzed, with the most expressive results being observed for calcium at a frequency of $93 \mathrm{~g} / \mathrm{Kg}$, whereas, molybdenum showed its higher frequency in the analyzed seeds of $1.0 \mathrm{~g} / \mathrm{Kg}$ obtaining in most of the seeds that varies in the 
scale of $1.00 \mathrm{~g} / \mathrm{Kg}$ to $2.81 \mathrm{~g} / \mathrm{Kg}$ (Charts 10 and 11). According to Lana et al. (2018) the treatment of soybean seed with the presence of molybdenum (Mo) results in significant increases in the productivity of this crop.

Graph 10: Frequency of Calcium $(\mathrm{Ca})$ present in the cultivars tested regardless of the state under study.

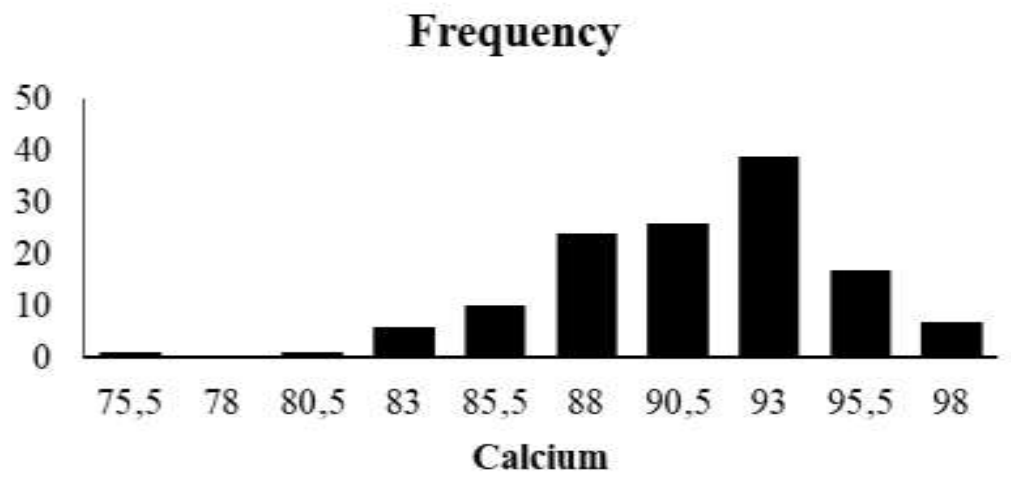

Source: Authors.

Graph 11: Frequency of Molybdenum (Mo) present in the cultivars tested, regardless of the state under study.

\section{Frequency}

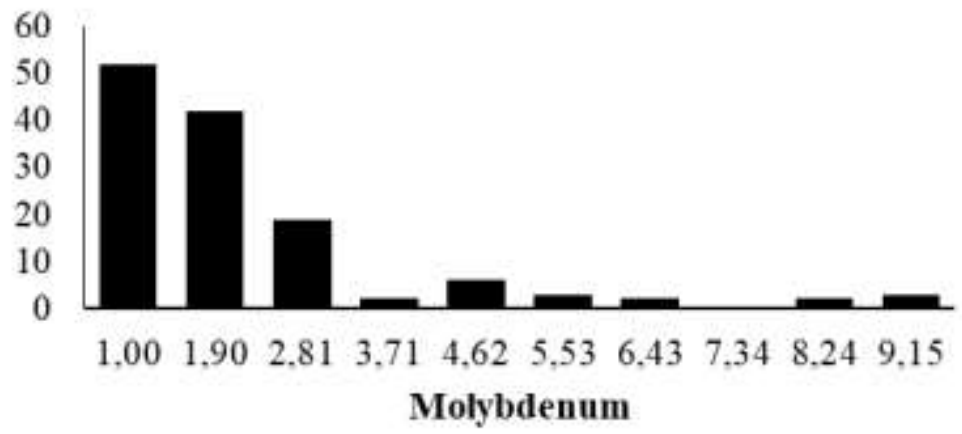

Source: Authors.

According to Malavolta (2016) in addition to playing a fundamental role in the assimilation of nitrogen (N) by composing the nitrate reductase enzyme, molybdenum (Mo) is a component of nitrogenase, an enzyme responsible for reducing $\mathrm{N}_{2}$ to $\mathrm{NH}_{3}$, in the process of biological $\mathrm{N}$ fixation $(\mathrm{FBN})$.

\section{Conclusion}

When it comes to the physiological quality analyzes of the 30 cultivars, 27 of them presented their results, which fall within the standards required by law for the marketing of seeds. The three southern states of Brazil did not show differences in the physiological quality of the tested cultivars.

For the presence of macronutrients, nitrogen $(\mathrm{N})$, phosphorus $(\mathrm{P})$ and potassium $(\mathrm{K})$, there was no significant difference in the levels present in the seeds in the three evaluated states. While Calcium (Ca) and Molybdenum (Mo) presented higher content when analyzing the seeds of Paraná. 
Finally, the physiological potential comprises the set of skills that allows estimating the capacity of a batch of seeds to properly manifest their vital functions after sowing.

\section{References}

Azevedo, M. R. Q. A, Gouveia, J. P. G, Trovao, D. M. M, \& Queiroga, V. P (2005). Influence of packaging and storage conditions on the vigor of sesame seeds. Brazilian Journal of Agricultural and Environmental Engineering, 7, 519-524.

Brazil. Ministry of Agriculture, Livestock and Supply (2009). Rules for seed analysis. SNAD / DNPV / CLAV. 399p.

Carvalho, N. M., \& Nakagawa, J. (2016). Seeds: Science, Technology and Production. (6a ed.), Cargill Foundation. 400p.

CONAB. National Supply Company (2018). Monitoring of the Brazilian grain harvest, crop - Sixth survey. CONAB. 140p.

CONAB. National Supply Company (2016). Historical series of grain production.

CSM / RS (2016). Catalog of producers of seeds and seedlings of Rio Grande do Sul 2015/2016. RS Seeds and Seedlings Commission (CSM / RS). RS Seeds and Seedlings Commission. $156 \mathrm{p}$.

Delarmelino - Ferraresi, L. M., Villela, F.A, Aumonde, T. Z (2014). Physiological performance and chemical composition of soybean seeds. Revista Brasileira Ciência Agrária, 9, 14-18.

DERAL (2019) - Department of Rural Economy of the Secretary of State for Agriculture and Supply.

Epstein, E., Bloom, A.J (2016). Mineral plant nutrition: principles and perspectives. Planta. 410p.

Farinelli, R., Penariol, F. G., Souza, F. S. et al. (2016). Agronomic characteristics and physiological quality of seeds of soybean cultivars fertilized via foliar with calcium and boron. Scientific (Jaboticabal. Online), 34: 59-65.

Fessel, S. A., Panobianco, M., Souza, C. R., \& Vieira, R. D. (2018). Electrical conductivity test on soybean seeds stored under different temperatures. Bragantia, Campinas, 69(1), 207-214.

Flores, M. F., Monnerat, P. H., Nováis, R. F., \& Neves, J. C. L. (2015). Foliar nutrition: principles and recommendations. Agricultural Report, 7, 54-62.

Hennigen, France Neto, J. B. \& Krzyzanowski, F. (2015). Maximum productivity with the use of high vigor soybean seeds. ABRASEM Guide.

Krzyzanowski, F. C., France Neto, J. B., Henning, A. A., \& Costa, N. P. (1999). Quality control adding value to soybean seed - Seeds Series. Londrina: Embrapa Soja. 12p.

Lana, Q. M. R., Pereira, R. P., Lana, A. M. Q. et al. (2018). Use of micronutrients in soybean cultivation under no-tillage system. Bioscience Journal, 24: 5863.

Malavolta, E. (2016). Mineral plant nutrition manual. Agronômica Ceres. 638p.

MAP. Ministry of Agriculture, Livestock and Supply (2017). Brazil agribusiness projections 2016/2017 to $2026 / 2027$.

Mielezrski, F., Schuch, L. O. B., Peske, S. T., Panozzo, L. E., Carvalho, R. R., \& Zuchi, J (2008). Field performance of isolated hybrid rice plants as a function of seed physiological quality. Revista Brasileira de Sementes, 30, 139-144.

Peske, S. T., Barros, A. C. S. A., \& Schuch, L. O. B (2010). Benefits and obtaining high quality seeds. Seednews, year 14(5).

Santos, M., \& Silveira, M. L (2017). Brazil: territory and society at the beginning of the 21 st century. Limited Ed. Record.

Silva, S. A., Moraes, W. B. \& Souza, G. S (2011). Doses of calcium in the growth of soybean grown in nutrient solution, in the presence of aluminum. Idesia (Arica), 29: 53-58.

Steiner, A. M., \& Kruse, M (2003). On the origin and rise of topographical tetrazolium testing - a brief historical retrospect. In: Leist, N., Kramer, S., Jonitz, A. (Ed.). Bassersdorf: ISTA Tetrazolium Committee. Working Sheets on Tetrazolium Testing, 1, 1-5.

Tedesco, M. J., et al. (1995). Analysis of soil, plants and other materials. Federal University of Rio Grande do Sul. 174p. Technical bulletin, vol. 5.

Veiga, D. A., Von Pinho E. V. R., Veiga, A., Pereira, P. H. A. R., Oliveira, K. C., \& Von Pinho, R.G (2010). Influence of potassium and lime on chemical composition, physiological quality and enzymatic activity of soybean seeds. Science and Agrotechnology, 34(4), 953-960.

Ziegler, P. (1995). Carbo hydrate and gradation during germination. In: Kigel, J., \& Galili, G. (Ed.). Seed development and germination. Marcel Dekker. 447474 .

Zimmer, P. D. Fundamentals of seed quality. In: Peske, S. T., Villela, F. A., \& Meneghello, G. E (Orgs.) (2012). Seeds: scientific and technological foundations. (3a ed.), Publisher. University / UFPel. 106-16. 